\title{
Hormonal control of proteins synthesized and secreted by guinea-pig endometrium
}

\author{
F. Abdi-Dezfuli and N. L. Poyser* \\ Department of Pharmacology, University of Edinburgh Medical School, 1 George Square, Edinburgh, \\ EH8 9JZ, UK
}

\begin{abstract}
The amounts of protein synthesized and secreted (as indicated by $\left[{ }^{3} \mathrm{H}\right]$ leucine incorporation) by guinea-pig endometrium cultured for $24 \mathrm{~h}$ increased 2.1-fold between days 7 and 15 of the oestrous cycle. This increase did not occur if the guinea-pigs were pregnant. In ovariectomized guinea-pigs, oestradiol acting on a progesterone-primed uterus was the optimum stimulus for the maximum increase in endometrial protein synthesis and secretion. The two main proteins synthesized and secreted by day-15 guinea-pig endometrium had molecular masses of 99.8 and $192.1 \mathrm{kDa}$ as determined on Sephacryl S-200HR. The production of the $99.8 \mathrm{kDa}$ protein increased 5.2 -fold between days 7 and 15 of the cycle. The $192.1 \mathrm{kDa}$ protein was not detected in secretions produced by day 7 endometrium, and the 99.8 and $192.1 \mathrm{kDa}$ proteins were not detected in secretions produced by day-15 pregnant endometrium. In ovariectomized guinea-pigs, progesterone did not stimulate the synthesis of secreted proteins of molecular masses above $77 \mathrm{kDa}$. Oestradiol stimulated the synthesis of secreted proteins with molecular masses of 87.8 and $192.1 \mathrm{kDa}$. However, oestradiol acting on a progesterone-primed uterus stimulated the synthesis of the secreted proteins with molecular masses of 99.8 and $192.1 \mathrm{kDa}$, which indicates that this combination of steroid hormones may be responsible for the increase in production of these two proteins by the day-15, nonpregnant guinea-pig endometrium. This stimulation by ovarian steroids of the synthesis and secretion of the 99.8 and $192.1 \mathrm{kDa}$ proteins by the guinea-pig endometrium is apparently inhibited during early pregnancy.
\end{abstract}

\section{Introduction}

Oestradiol administration after progesterone treatment is the optimum stimulus for increasing prostaglandin $\mathrm{F}_{2 \alpha}\left(\mathrm{PGF}_{2 \alpha}\right)$ output from the uterus of ovariectomized guinea-pigs (Blatchley and Poyser, 1974; Poyser, 1983a). In intact guinea-pigs, oestradiol output from the ovary increases after day 10 of the cycle (Joshi et al., 1973) and this increase precedes the increase in $\mathrm{PGF}_{2 \alpha}$ output from the uterus by $24 \mathrm{~h}$ (Blatchley et al., 1972; Earthy et al., 1975; Antonini et al., 1976). In guinea-pigs, oestradiol acting on a progesteroneprimed uterus is therefore the physiological stimulus for increased synthesis of $\mathrm{PGF}_{2 a}$ by the endometrium. Oxytocin has no stimulatory effect on endometrial $\mathrm{PGF}_{2 \alpha}$ production in this species (Poyser and Brydon, 1983; Riley and Poyser, 1987).

The major mechanism by which oestradiol exerts its effects (following combination with its nuclear receptor) is by stimulating the production of specific RNAs that carry the information required for the synthesis of new proteins which in turn bring about physiological changes in target cells (Brenner and West, 1975). Actinomycin D, cycloheximide, puromycin and sodium fluoride (all inhibitors of protein synthesis) significantly reduce the outputs of $\mathrm{PGF}_{2 \alpha^{\prime}} \mathrm{PGE}_{2}$ and 6-keto-PGF ${ }_{1 \alpha}$ from day-15 guinea-pig endometrium when included in the culture

${ }^{*}$ Reprint requests.

Received 11 February 1992 medium, and the output of $\mathrm{PGF}_{2 \alpha}$ is particularly affected during the first $6 \mathrm{~h}$ of culture (Riley and Poyser, 1989; Leckie and Poyser, 1990). The intrauterine administration of actinomycin $D$ to guinea-pigs on day 10 of the cycle decreases the outputs of $\mathrm{PGF}_{2 \alpha}$ and $\mathrm{PGE}_{2}$, but not of 6-keto-PGF ${ }_{1 \alpha^{\prime}}$, from day-15 endometrium, but not myometrium, in culture and from the day- 15 uterus superfused in vitro (Poyser and Riley, 1987; Riley and Poyser, 1989). The simultaneous administration of oestradiol does not overcome this inhibitory effect of actinomycin D (Poyser and Riley, 1987). The synthesis of secreted proteins, but not of cellular proteins, is significantly greater by day- 15 than by day -7 guinea-pig endometrium in culture. Actinomycin D, cycloheximide, puromycin and sodium fluoride in concentrations that inhibit endometrial PG synthesis also inhibit endometrial protein synthesis (Riley and Poyser, 1989; Leckie and Poyser, 1990). In addition, the intrauterine administration of actinomycin $\mathrm{D}$ on day 10 significantly reduces the synthesis of proteins by day-15 endometrium in culture (Riley and Poyser, 1989). These findings indicate that the stimulation of endometrial $\mathrm{PGF}_{2 \alpha}$ synthesis in guinea-pigs by oestradiol acting on a progesteroneprimed uterus depends on increased endometrial protein synthesis.

Previous studies have shown that the increases in the amounts of phospholipase $A_{2}\left(P_{2} A_{2}\right)$ and PG endoperoxide synthase in the endometrium after day 10 of the cycle are not responsible for 'switching on' endometrial $\mathrm{PGF}_{2 \alpha}$ synthesis (Downing and Poyser, 1983; Poyser, 1983b). These findings 
indicated that the activation of $\mathrm{PLA}_{2^{\prime}}$ probably as a result of raising the intracellular free $\mathrm{Ca}^{2+}$ concentration was the ratelimiting step in endometrial PGF $_{2 \alpha}$ synthesis (Downing and Poyser, 1983; Poyser and Brydon, 1983). Subsequently, it was suggested that oestradiol acts on a progesterone-primed uterus to cause the synthesis of a protein which directly or indirectly raises the intracellular free $\mathrm{Ca}^{2+}$ concentration and thereby activates $\mathrm{PLA}_{2}$ (Poyser and Riley, 1987). In the present study, the production of secreted proteins by the endometrium has been examined (i) in guinea-pigs on day 7 and day 15 of the cycle (days of low and high PGF $_{2 \alpha}$ output, respectively), (ii) in ovariectomized guinea-pigs treated with progesterone, oestradiol or both, and (iii) in day-15 pregnant guinea-pigs, since uterine $\mathrm{PGF}_{2 a}$ production is suppressed in early pregnancy (Blatchley et al., 1975; Antonini et al., 1976; Poyser, 1984).

\section{Materials and Methods}

\section{Animals and treatments}

Virgin guinea-pigs weighing 500-950 g were examined daily and a vaginal smear was taken when the vagina was perforate. Day 1 of the cycle was defined as the day preceding the post-ovulatory influx of leucocytes when cornification was at a maximum. All guinea-pigs had exhibited at least two normal cycles before being used in the experiments described below. The animals were killed by stunning and incising the neck. In all experiments, the uterus was removed and small pieces of the endometrium were cultured in $4 \mathrm{ml}$ Medium 199 (plus Earle's salts, and supplemented with glutamine, amphotericin B and kanamycin) for $24 \mathrm{~h}$ as described previously (Riley and Poyser, 1989). The endometrium remains viable during this period. After culture, the culture medium was retained for protein analysis, and the dry weight of the culture endometrium was determined by heating the tissue at $37^{\circ} \mathrm{C}$ in an oven for $24 \mathrm{~h}$ followed by weighing.

\section{Materials}

L- $\left[4,5-{ }^{3} \mathrm{H}\right]$ Leucine (sp. act. 122 to $186 \mathrm{Ci} \mathrm{mmol}^{-1}$ ) and D-[6${ }^{3} \mathrm{H}$ ]glucosamine (sp. act. $32 \mathrm{Ci} \mathrm{mmol}^{-1}$ ) were purchased from Amersham International Ltd, Cardiff; MW-GF-200 calibration kit for molecular masses 12-200 kDa, DEAE-Sepharose CL-6B, CMSepharose CL-6B, Coomassie blue stain, oestradiol benzoate and progesterone were purchased from Sigma Chemical Co., Poole, Dorset; low molecular mass electrophoresis calibration kit (14.4 to $94 \mathrm{kDa}$ ), Blue Sepharose CL-6B, Sephacryl S-200HR and Columns PD-10 (for desalting) were purchased from Pharmacia LKB Biotechnology Ltd, Milton Keynes; Medium 199 (plus Earle's salts), glutamine, amphotericin B and kanamycin were purchased from Flow Labs, Irvine; peanut oil was purchased from BDH Chemicals Ltd, Poole.

\section{Experiment 1: quantitative analysis of total protein released from guinea-pig endometrium}

The uteri from five day-7 and five day-15 guinea-pigs were used. The endometrium obtained from each uterus was cultured in 12 dishes each containing $20-30 \mathrm{mg}$ tissue. After culture, the

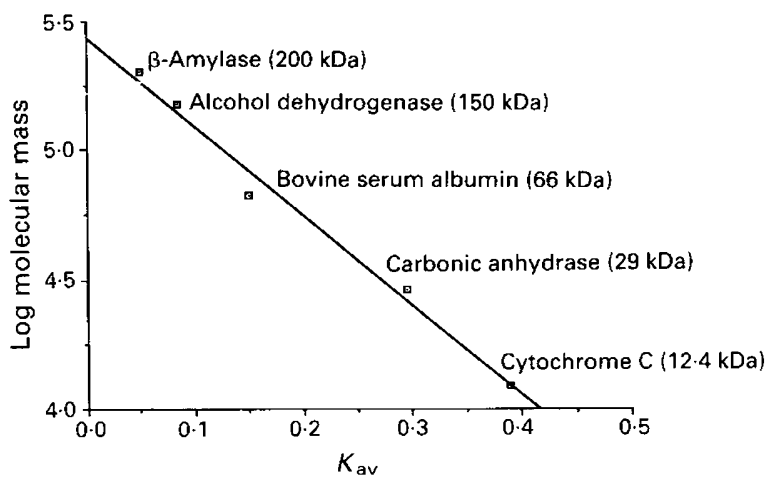

Fig. 1. Calibration curve obtained with standard proteins run on a Sephacryl S-200HR column $(1.6 \mathrm{~cm} \times 97 \mathrm{~cm})$. The best line of fit was produced using simple regression $(r=0.99)$. The figures in brackets indicate the approximate molecular mass of the standard proteins.

media from the 12 dishes were pooled and dialysed four times using $5 \mathrm{l}$ of $2 \mathrm{mmol}$ Tris- $-\mathrm{HCl} \mathrm{l^{-1 }}$ buffer at $\mathrm{pH} 8.2$ over $48 \mathrm{~h}$. The dialysed medium was lyophilized. The lyophilate was dissolved in $2.5 \mathrm{ml}$ water and loaded onto a desalting column that contained 9.1 ml Sephadex G-25 swollen gel resin (Column PD10) which had been equilibrated with $25 \mathrm{ml}$ water. The desalted protein was eluted from the column by $3.5 \mathrm{ml}$ water, and $0.1 \mathrm{ml}$ of the eluate was subsequently used for protein measurement (Lowry et al., 1951). The remaining $3.4 \mathrm{ml}$ was lyophilized. The lyophilate was weighed, redissolved in $1 \mathrm{ml}$ Tris- $\mathrm{HCl}$ buffer $\left(50 \mathrm{mmol} \mathrm{l}^{-1} ; \mathrm{pH} \mathrm{7)}\right.$ containing $0.1 \mathrm{mmol} \mathrm{KCl} \mathrm{l}^{-1}$ and $5 \%$ glycerol, and passed down an affinity column containing Blue Sepharose CL-6B to remove contaminating albumin from the sample. The albumin-free protein was eluted from the column by Tris- $\mathrm{HCl}$ buffer $\left(50 \mathrm{mmol} \mathrm{l}^{-1}, \mathrm{pH} 7\right)$, and the eluate was dialysed, desalted and the amount of protein present measured as described above.

\section{Experiment 2: analysis of total secreted proteins synthesized de novo by guinea-pig endometrium}

The uteri from five day- 7 and five day-15 guinea-pigs were used. The endometrium obtained from each uterus was distributed among eight dishes. Each dish contained $30-50 \mathrm{mg}$ tissue and $10 \mu \mathrm{Ci}\left[{ }^{3} \mathrm{H}\right]$ leucine. After culture, the medium from the eight dishes was pooled, and the amount of $\left[{ }^{3} \mathrm{H}\right]$ leucine incorporated into endometrial secreted proteins was measured as described by Riley and Poyser (1989). The medium was then dialysed and lyophilized as in Expt 1. Lyophilates of the proteins secreted by day-7 and day- 15 guinea-pig endometrium in culture were then combined for each day, desalted and re-lyophilized (as in Expt 1) to give two respective protein pools. Both pools of protein were then passed through a Blue Sepharose CL-6B column to remove albumin, and the eluate was dialysed, desalted and assayed for protein content as in Expt 1 . The protein solution was lyophilized and weighed.

Portions (7-20 mg) of the day-7 and day- 15 secreted proteins were subjected to gel filtration chromatography on Sephacryl S-200HR using Tris- $\mathrm{HCl}$ buffer $\left(10 \mathrm{mmol} \mathrm{l}^{-1}\right.$, $\mathrm{pH}$ 8.2) containing $0.33 \mathrm{~mol} \mathrm{NaCl} \mathrm{l}^{-1}$. The column had previously been calibrated with proteins of known molecular mass (Fig. 1). Two forms of elution profile were then generated for 
each fractionated sample: (i) an 'A-280 nm elution' profile, which was constructed by measuring continuously the UV absorbance at $280 \mathrm{~nm}$ of the eluate as it passed through a UV monitor and which indicated proteins present, and (ii) a 'radioactivity' profile, which was constructed by measuring the amount of radioactivity present in $200 \mu \mathrm{l}$ aliquots removed from each $2 \mathrm{ml}$ fraction of eluate and which indicates proteins synthesized by the endometrium. Fractions of eluate containing proteins of low $(<30 \mathrm{kDa})$, medium $(30-150 \mathrm{kDa})$ and high ( $>150 \mathrm{kDa}$ ) molecular masses were combined to give three respective pools of protein. Each pool was dialysed, desalted, the protein content measured, and lyophilized as in Expt 1 . Portions of each pool of protein were then subjected to ionexchange chromatography using DEAE-Sepharose CL-6B and Tris- $\mathrm{HCl}$ buffer (10 $\mathrm{mmol}^{-1}, \mathrm{pH} \mathrm{8.2)}$ with increasing concentrations of $\mathrm{NaCl}$ between 0 and $0.5 \mathrm{~mol} \mathrm{l}^{-1}$ as the eluant, or using CM-Sepharose CL-6B and $50 \mathrm{mmol} \mathrm{l}^{-1}$ phosphate buffer ( $\mathrm{pH}$ 8.2) with increasing $\mathrm{NaCl}$ concentrations between 0 and $0.5 \mathrm{~mol} \mathrm{l}^{-1}$ as eluant. Two profiles of the eluted proteins (i.e. 'A$280^{\prime}$ and 'radioactivity') were obtained as described above.

The remaining day-7 and day-15 secreted proteins which were not subjected to gel filtration chromatography were analysed by polyacrylamide gel electrophoresis performed in the presence of sodium dodecyl sulfate (SDS-PAGE), as described by Laemmli (1970), using a Protean II Slab Cell (BioRad Laboratories Ltd, Watford) for vertical electrophoresis. The protein samples and standard proteins were run simultaneously on homogenous polyacrylamide $(12 \%)$ gels, which were subsequently visualized by Coomassie blue staining. 'Radioactivity' profiles were constructed for each electrophoresed sample using a gel slicing technique based on the method used by Basha $e t$ al. (1979). Each gel of each protein sample was sliced into $1.5-1.6 \mathrm{~mm}$ sections and each section was placed in a $6 \mathrm{ml}$ scintillation vial followed by $0.3 \mathrm{ml}$ hydrogen peroxide $(30 \% \mathrm{v} / \mathrm{v})$. The vials were then incubated at $70^{\circ} \mathrm{C}$ for $24 \mathrm{~h}$, then filled with scintillation fluid, and the amount of radioactivity present estimated. Molecular masses of the radioactive proteins were calculated from their $R_{\mathrm{F}}$ values in comparison with the $R_{\mathrm{F}}$ values of the standard proteins.

This experiment was repeated using a further 10 guinea-pigs and $10 \mu \mathrm{Ci}\left[{ }^{3} \mathrm{H}\right] g$ lucosamine instead of $\left[{ }^{3} \mathrm{H}\right]$ leucine, but the analysis by SDS-PAGE was not included.

\section{Experiment 3: effects of treatment with ovarian steroid hormones in vivo on endometrial protein secretion}

Ovariectomized guinea-pigs (five per group) were injected s.c. once a day for 10 days with $0.5 \mathrm{ml}$ peanut oil with the following additions: (i) no additions (control), (ii) $2.5 \mathrm{mg}$ progesterone, (iii) no additions for 7 days, followed by $10 \mu \mathrm{g}$ oestradiol benzoate for 3 days, (iv) $2.5 \mathrm{mg}$ progesterone for 7 days, followed by $2.5 \mathrm{mg}$ progesterone plus $10 \mu \mathrm{g}$ oestradiol benzoate for 3 days.

The uterus was removed from each guinea-pig on the day after the last day of treatment. The endometrium obtained from each uterus was distributed among 12 culture dishes (15-30 mg tissue per dish). After culture, the medium obtained from each dish was pooled and subjected to the procedures described in Expt 1.

A further 20 ovariectomized guinea-pigs were treated as described above (five animals per group). The endometrium
Table 1. Mean ( \pm SEM, $n=5$ ) amounts of protein secreted ( $\mu \mathrm{g}$ $\mathrm{mg}^{-1}$ dry tissue) by day-7 and day-15 nonpregnant, and by day-15 pregnant endometrium cultured for $24 \mathrm{~h}$ before and after removal of serum albumin by Blue Sepharose CL-6B

\begin{tabular}{|c|c|c|c|}
\hline \multirow[b]{2}{*}{ Day } & \multicolumn{2}{|c|}{ Nonpregnant } & \multirow{2}{*}{ Pregnant } \\
\hline & 7 & 15 & \\
\hline $\begin{array}{l}\text { Before removal of } \\
\text { serum albumin }\end{array}$ & $153.5 \pm 7.9$ & $182.5 \pm 16.5$ & $111.0 \pm 6.9^{*}$ \\
\hline $\begin{array}{l}\text { After removal of } \\
\text { serum albumin }\end{array}$ & $48.6 \pm 6.5 \dagger$ & $73.3 \pm 8.6$ & $14.8 \pm 1.2^{*}$ \\
\hline
\end{tabular}

*Significantly $(P<0.01)$ lower than corresponding day-7 and day-15 nonpregnant values.

†Significantly $(P<0.05)$ lower than corresponding day-15 nonpregnant value.

from each animal was distributed among eight culture dishes. Each dish contained $25-45 \mathrm{mg}$ tissue and $10 \mu \mathrm{Ci}\left[{ }^{3} \mathrm{H}\right]$ leucine. After culture, the media from the eight dishes were pooled, and purified by dialysis, desalting and chromatography on Blue Sepharose CL-6B and Sephacryl S200-HR as described in Expt 2.

\section{Experiment 4: effect of pregnancy on endometrial protein secretion}

Day 1 of pregnancy was defined as the day spermatozoa were present in the vaginal smear or there were external signs of mating. The uterus was removed from five guinea-pigs on day-15 of pregnancy. The endometrium from each uterus was distributed among 12 culture dishes (15-30 mg tissue per dish). After culture, the media from the 12 dishes were pooled and treated as in Expt 1 .

The uteri from a further five day-15 pregnant guinea-pigs were removed, and the endometrium from each uterus was distributed among eight culture dishes. Each dish contained 25$45 \mathrm{mg}$ tissue and $10 \mu \mathrm{Ci}\left[{ }^{3} \mathrm{H}\right]$ leucine. After culture, the media from the eight dishes were pooled and purified by dialysis, desalting and chromatography on Blue-Sepharose CL-6B and Sephacryl S200-HR and the proteins were analysed by SDSPAGE as described in Expt 2.

\section{Statistical analysis}

Results were analysed by Student's $t$ test or, if the variances of the two groups were significantly different by the variance ratio $F$ test, by a modified $t$ test for unequal variances.

\section{Results}

\section{Quantitative assessment of endometrial protein secretion}

Total protein. The total amount of protein secreted by guinea-pig endometrium cultured for $24 \mathrm{~h}$ was higher on day 15 of the cycle than on day 7 of the cycle and on day 15 of pregnancy, although this difference was significant $(P<0.01)$ only for day 15 of the cycle and day 15 of pregnancy (Table 1). 
Table 2. Mean ( $\pm \operatorname{SEM}, n=5$ ) amounts of protein secreted $\left(\mu \mathrm{g} \mathrm{mg} \mathrm{g}^{-1}\right.$ dry tissue) by endometrium cultured for $24 \mathrm{~h}$ from ovariectomized guinea-pigs treated with peanut oil (control), progesterone, oestradiol, and progesterone plus oestradiol before and after removal of serum albumin by Blue Sepharose CL-6B

Treatment

\begin{tabular}{ccrc}
\hline Control & Progesterone & Oestradiol & $\begin{array}{c}\text { Progesterone } \\
\text { plus oestradiol }\end{array}$ \\
$98.9 \pm 9.7$ & $127.7 \pm 10.4$ & $205.9 \pm 22.9^{*}$ & $173.9 \pm 11.5^{*}$ \\
$17.5 \pm 1.6$ & $26.0 \pm 4.3$ & $74.9 \pm 10.5^{*}$ & $52.7 \pm 4.3^{*}$ \\
\hline
\end{tabular}

*Significantly $(P<0.05)$ higher than corresponding control and progesterone only values.

After the removal of albumin by Blue Sepharose CL-6B, the amount of protein secreted by guinea-pig endometrium was significantly higher on day 15 of the cycle than on day 7 of the cycle $(P<0.05)$ and on day 15 of pregnancy $(P<0.01$; Table 1). In both instances the amount of protein secreted by the day15 pregnant endometrium was significantly $(P<0.01)$ lower than the amount secreted by the day-7 endometrium.

In ovariectomized guinea-pigs, progesterone treatment alone had no significant effect on the amount of protein secreted by the endometrium before and after purification on Blue Sepharose CL-6B. Oestradiol treatment alone and in combination with progesterone significantly $(P<0.05)$ stimulated the amount of protein secreted by the endometrium before and after purification on Blue Sepharose CL-6B (Table 2).

Proteins labelled with radioactivity. The amount of $\left[{ }^{3} \mathrm{H}\right] \mathrm{leu}-$ cine incorporated into proteins synthesized and secreted by the endometrium was significantly $(P<0.05)$ higher on day 15 of the cycle than on day 7 of the cycle and on day 15 of pregnancy (Fig. 2a). The amounts of radioactivity incorporated into proteins secreted by the endometrium when cultured in the presence of $\left[{ }^{3} \mathrm{H}\right]-$ glucosamine were $5148 \pm 881$ and $3809 \pm 644$ d.p.m. $\mathrm{mg}^{-1}$ tissue per $10^{-6}$ standard d.p.m. added ml $\mathrm{m}^{-1}$ on days 15 and 7 of the cycle, respectively, but this difference was not statistically significant.

In ovariectomized guinea-pigs, progesterone treatment caused a small, but significant $(P<0.05)$ increase in the amount of $\left[{ }^{3} \mathrm{H}\right]-$ leucine incorporated into proteins synthesized and secreted by the endometrium. Oestradiol treatment alone caused a much larger and significant $(P<0.05)$ increase in the amount of $\left[{ }^{3} \mathrm{H}\right]$ leucine incorporated into secreted endometrial proteins, but treatment with progesterone and oestradiol produced the largest increase in the amount of $\left[{ }^{3} \mathrm{H}\right] \mathrm{leucine}$ incorporated into secreted endometrial proteins and this increase was significantly $(P<0.05)$ greater than with oestradiol alone (Fig. 2b).

\section{Qualitative and quantitative analysis of endometrial protein secretion}

\section{Analysis by Sephacryl S-200HR}

In intact guinea-pigs the absorbance $\left(A_{280}\right)$ profile of day-7 endometrial proteins showed that most proteins were eluted in the void volume and had molecular masses $>250 \mathrm{kDa}$. How-

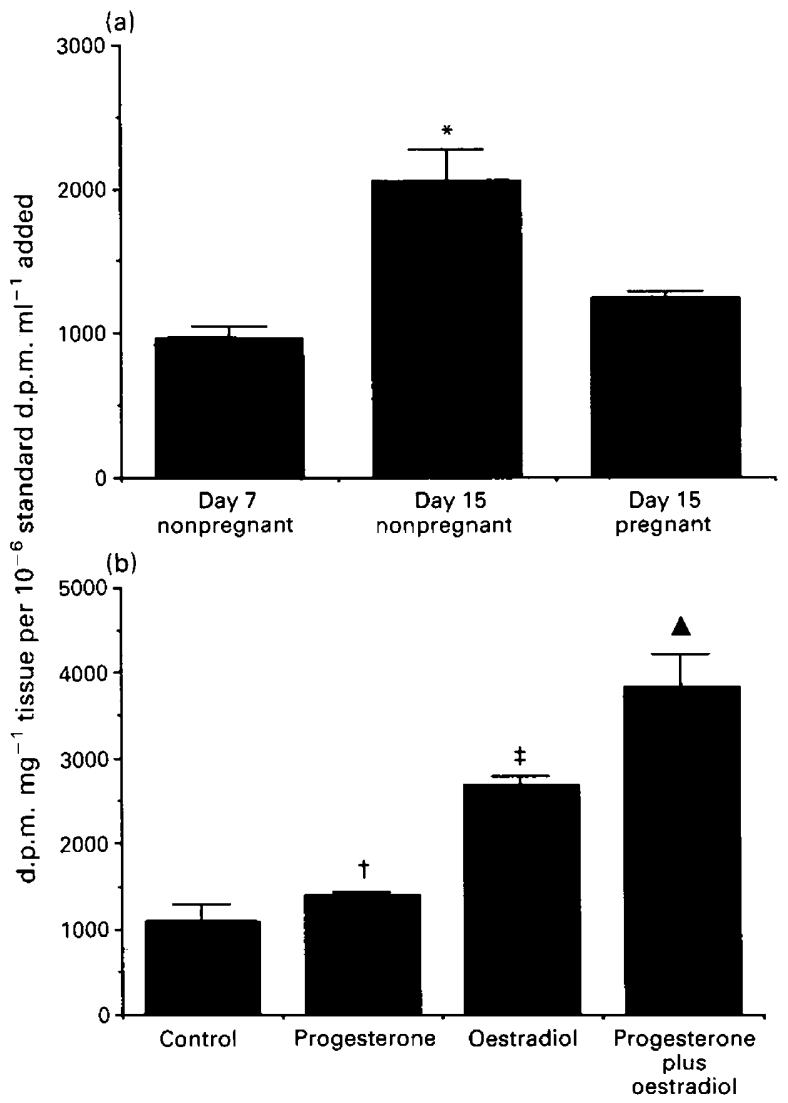

Fig. 2. Mean ( $\pm \operatorname{SEM}, n=5$ ) amounts of $\left[{ }^{3} \mathrm{H}\right]$ leucine incorporated into secreted proteins synthesized de novo by endometrium cultured for $24 \mathrm{~h}$ from (a) day-7 nonpregnant, day-15 nonpregnant, and day-15 pregnant guinea-pigs, and (b) ovariectomized guinea-pigs treated with peanut oil (control), progesterone, oestradiol, and progesterone plus oestradiol.

${ }^{*}$ Significantly $(P<0.05)$ higher than day-7 nonpregnant and day-15 pregnant values.

† Significantly $(P<0.05)$ higher than control value.

†़Significantly $(P<0.05)$ higher than control and progesterone-treated values.

$\Delta$ Significantly $(P<0.05)$ higher than control, progesterone-treated and oestradiol-treated values.

ever, there was a small peak at $99.8 \mathrm{kDa}$. Analysis of the radioactivity profile of $\left[{ }^{3} \mathrm{H}\right]$ leucine incorporation showed small peaks of radioactivity at $<5.6,8.4,10.9,14.1,18.4,35.2,59.4,99.8$, 


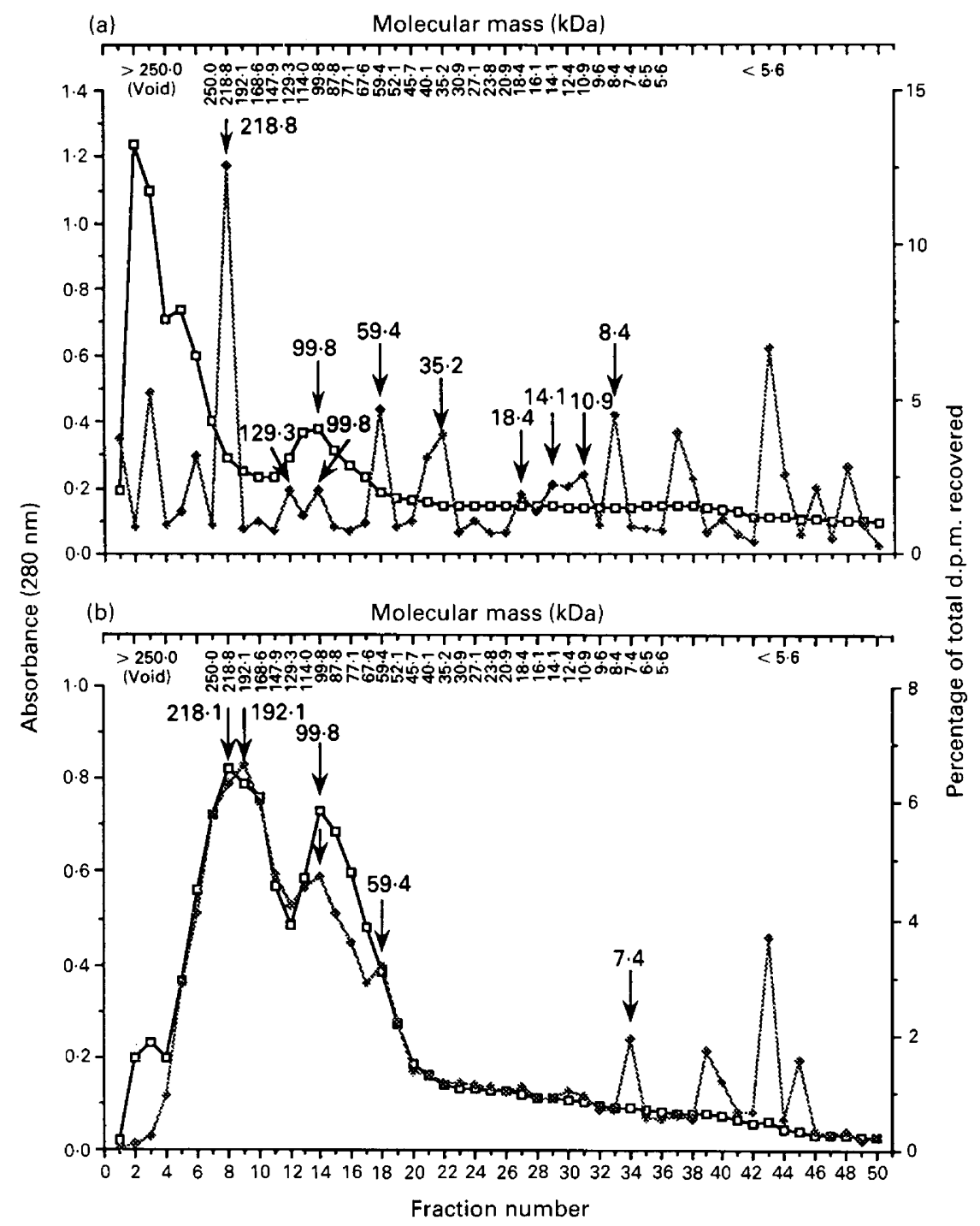

Fig. 3. UV absorbance $(280 \mathrm{~nm})(\square)$ and radioactivity (\% of total d.p.m. recovered; $\left[{ }^{3} \mathrm{H}\right]$ leucine-incorporation) ( $\bullet$ ) profiles of proteins secreted by (a) day-7 and (b) day-15 nonpregnant guinea-pig endometrium cultured for $24 \mathrm{~h}$, following analysis on Sephacryl S-200HR.

$129.3,218.8$ and $>250 \mathrm{kDa}$. The major peak of radioactivity was at $218.8 \mathrm{kDa}$ (Fig. 3a).

The absorbance $\left(A_{280}\right)$ profile of day-15 endometrial secreted proteins contained two major peaks at 99.8 and $218.8 \mathrm{kDa}$ and a small peak of protein which eluted with the void volume $(>250 \mathrm{kDa})$. The radioactivity profile showed peaks at $<5.6$, $7.4,59.4,99.8$ and $192.1 \mathrm{kDa}$. There may also be a radioactive protein on day 15 equivalent to the $218.8 \mathrm{kDa}$ protein seen on day 7 , since the radioactivity profile increases at the same time as the UV absorbance profile of the $218.8 \mathrm{kDa}$ protein (Fig. $3 \mathrm{~b}$ ). By comparing the areas under the radioactive peaks, the relative amounts of the 59.4 and $99.8 \mathrm{kDa}$ proteins synthesized and secreted by the endometrium increased 2.2- and 5.2-fold, respectively, between day 7 and day 15 of the cycle. In addition, a 192.1 $\mathrm{kDa}$ protein is present on day 15 which is not seen on day 7 . The $99.8 \mathrm{kDa}$ protein showed a small degree of glycosylation on both days (Fig. 4).
In ovariectomized guinea-pigs, there was insufficient protein remaining from ovariectomized (control) guinea-pigs for analysis by Sephacryl S-200HR. The absorbance $\left(A_{280}\right)$ profile of endometrial secreted proteins from progesterone-treated guinea-pigs showed peaks at <5.6, 52.1, 99.8 and $>250 \mathrm{kDa}$. However, radioactive peaks were present only at $<5.6,7.4,20.9,27.1,35.2,45.7$ and $77.1 \mathrm{kDa}$ (Fig. 5a). The $A_{280}$ profile of endometrial secreted proteins from oestradioltreated guinea-pigs showed peaks at 87.8, 218.8 and $<250 \mathrm{kDa}$. Radioactive protein peaks were present at $<5.6$, 7.4, 16.1, 20.9, 67.6, 87.8, 192.1, 250 and $>250 \mathrm{kDa}$ (Fig. 5b). The $A_{280}$ profile of endometrial secreted proteins from guinea-pigs treated with progesterone and oestradiol showed peaks of 87.8 and $>250 \mathrm{kDa}$. Radioactive protein peaks were present at $<5.6,9.6,27.1,99.8,192.1$ and $>250 \mathrm{kDa}$. There was also a small 'shoulder' on the $99.8 \mathrm{kDa}$ peak between 77.1 and $87.8 \mathrm{kDa}$ (Fig. 5c). 


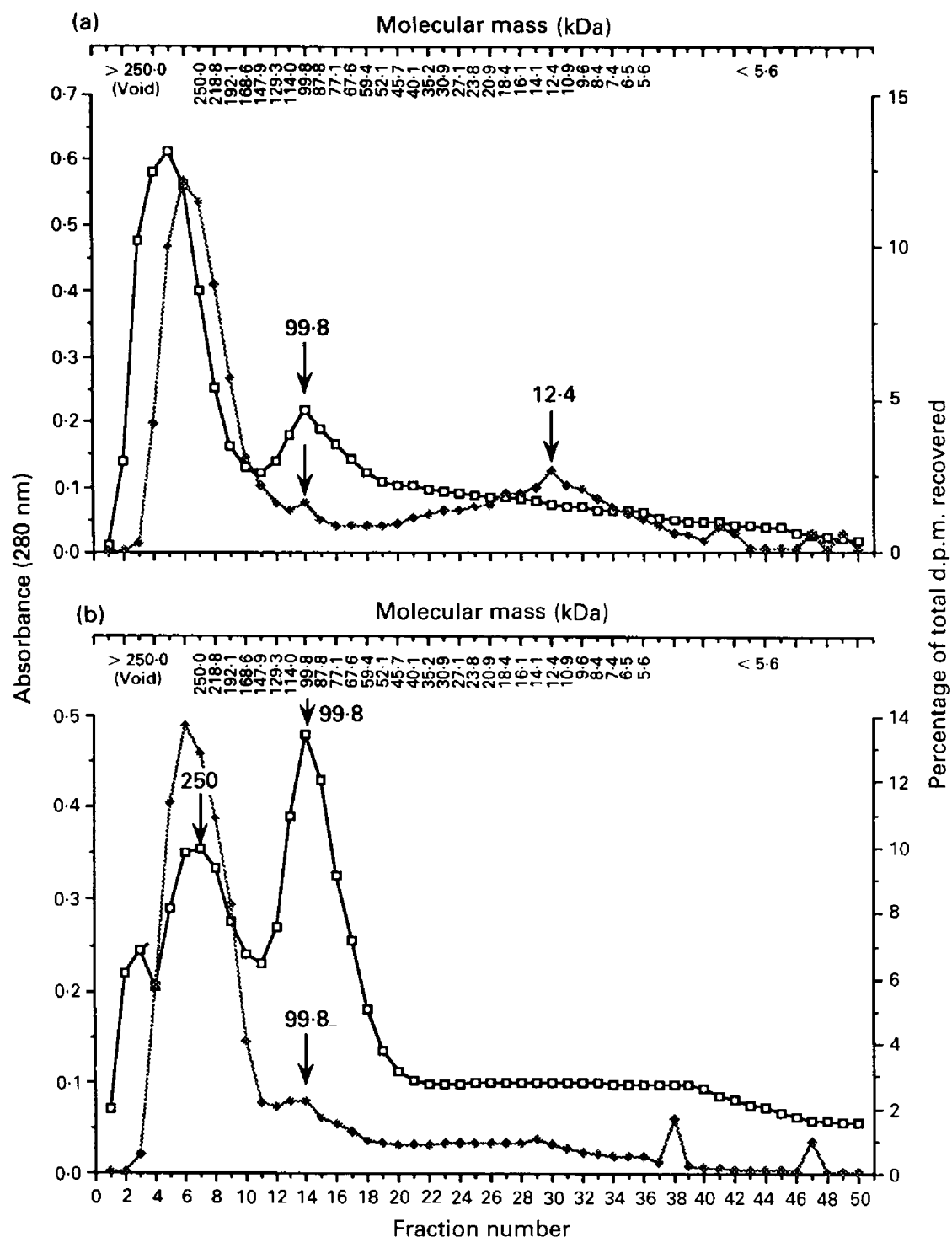

Fig. 4. UV absorbance $(280 \mathrm{~nm})(\square)$ and radioactivity (\% of total d.p.m. recovered; $\left[{ }^{3} \mathrm{H}\right]$ glucosamine-incorporation) $(\$)$ profiles of proteins secreted by (a) day-7 and (b) day-15 nonpregnant guinea-pig endometrium cultured for $24 \mathrm{~h}$, following analysis on Sephacryl S-200HR.

In pregnant guinea-pigs, the $A_{280}$ profile of proteins secreted by guinea-pig endometrium at day 15 of pregnancy showed peaks at 99.8 and $>250 \mathrm{kDa}$. Radioactive peaks were present at $<5.6,7.4,12.4,18.4,77.1,114.0,147.9$ and $250 \mathrm{kDa}$ (Fig. 6).

Analysis by ion exchange chromatography. Proteins of low, medium and high molecular masses secreted by day-7 and day-15 endometrium were retained on columns containing DEAE-Sepharose CL-6B but were not retained on columns containing CM-Sepharose CL- $6 \mathrm{~B}$ when the appropriate eluant buffer lacking $\mathrm{NaCl}$ was run through the columns. This shows that the proteins secreted by guinea-pig endometrium were acidic. The majority of the proteins retained on DEAESepharose CL- $6 \mathrm{~B}$ were eluted by the eluant buffer containing $0.2-0.3 \mathrm{~mol} \mathrm{NaCl} \mathrm{l}^{-1}$.
Analysis by SDS-PAGE. Analysis by SDS-PAGE of day-7 secreted endometrial proteins showed major bands of radioactivity at 54.1, 101.9, 108.4, and $126.5 \mathrm{kDa}$. There were also numerous smaller bands of radioactivity (Fig. 7a). The analysis of day-15 nonpregnant secreted endometrial proteins showed three major bands at $17.4,74.3$ and $81.3 \mathrm{kDa}$. There were also several smaller bands of radioactivity (Fig. $7 \mathrm{~b}$ ). The analysis of day-15 pregnant secreted proteins showed four major bands at $19.5,83.8,126.6$ and $147.6 \mathrm{kDa}$, together with many small bands of radioactivity (Fig. 7c).

\section{Discussion}

The UV absorbance profile indicates total protein secretion by the endometrium (i.e. preformed proteins that are present in the 

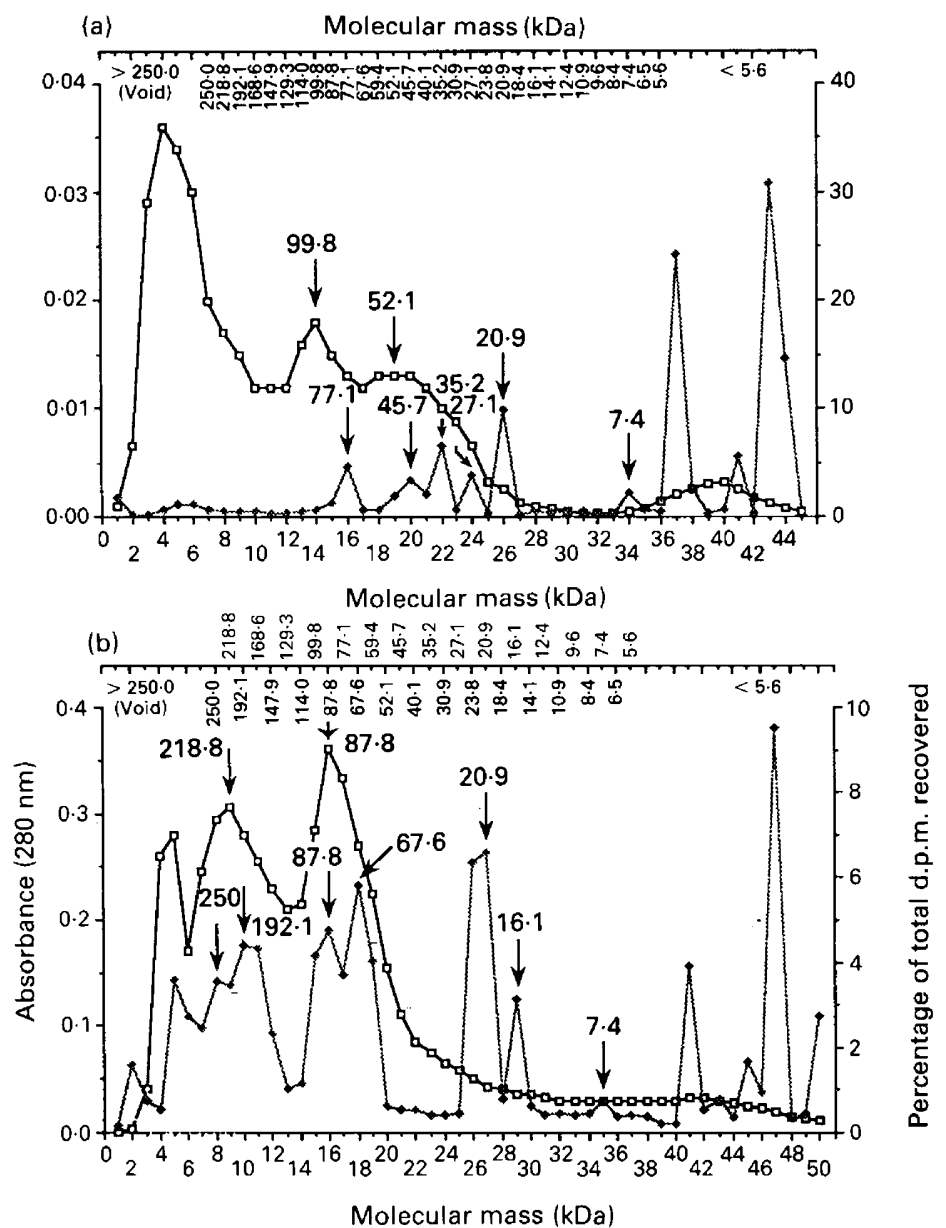

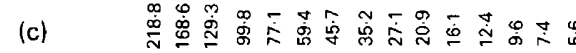

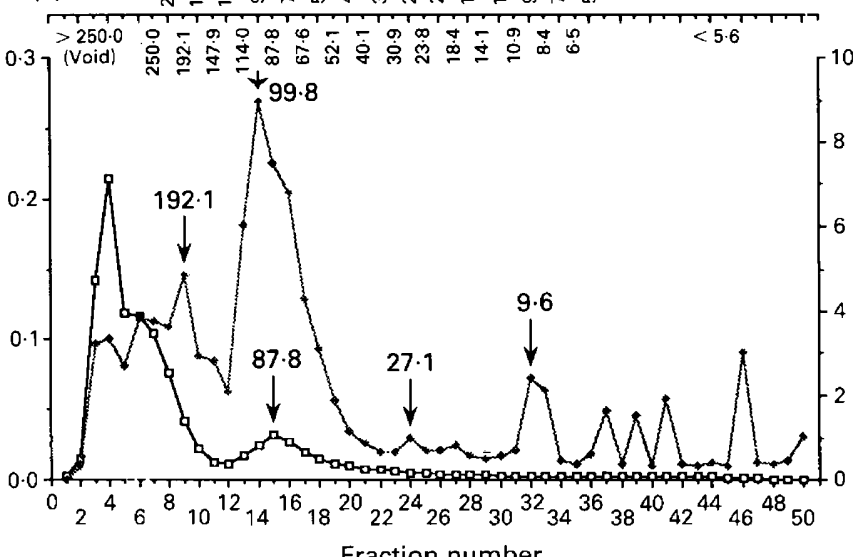

Fig. 5. UV absorbance $(280 \mathrm{~nm})(\square)$ and radioactivity (\% of total d.p.m. recovered $\left[{ }^{3} \mathrm{H}\right]$ leucine incorporation) $(\diamond)$ profiles of proteins secreted by endometrium cultured for $24 \mathrm{~h}$ from ovariectomized guinea-pigs treated with (a) progesterone, (b) oestradiol, and (c) progesterone plus oestradiol, after analysis on Sephacryl S-200HR.

endometrium and are secreted during the culture period plus proteins that are freshly synthesized and secreted by the endometrium during the culture period). The radioactivity profile indicates proteins that have been synthesized and secreted only during the culture period. This accounts for the discrepancy between the UV absorbance and radioactivity profiles since not all proteins that are secreted have been freshly synthesized. The amounts of albumin-free protein secreted by guinea-pig endometrium during $24 \mathrm{~h}$ of culture increased approximately twofold between day 7 and day 15 of the cycle. The increase did 


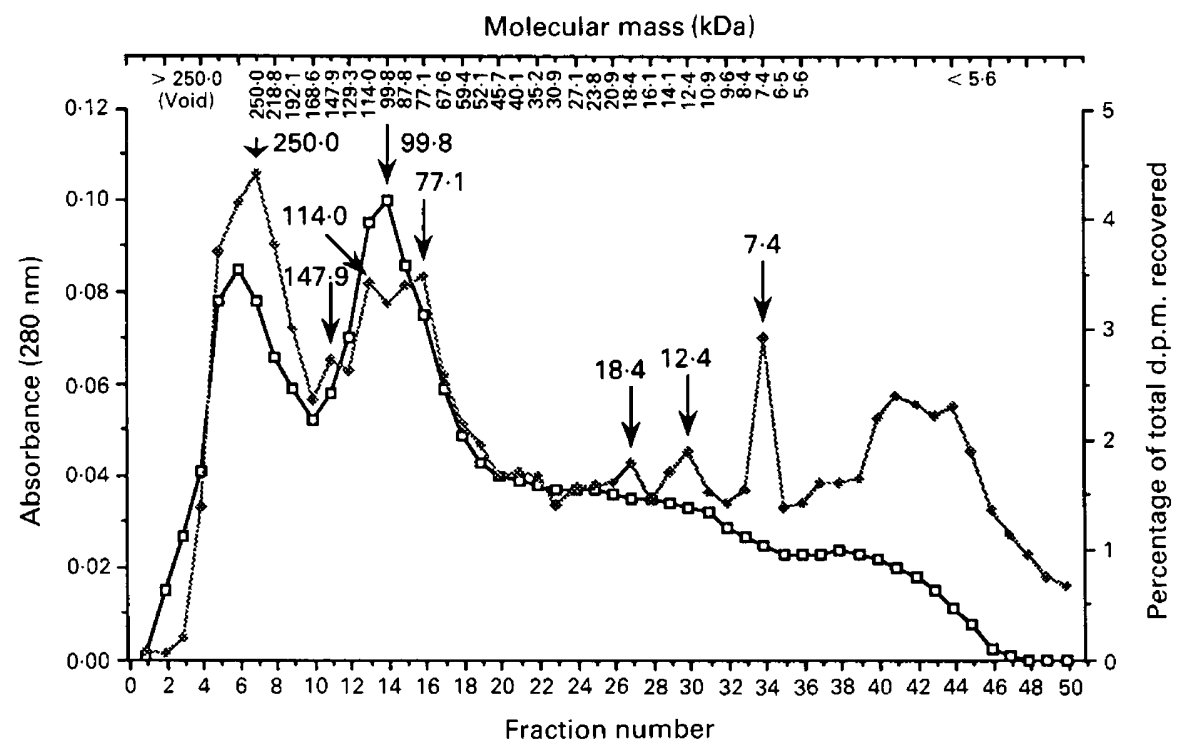

Fig. 6. UV absorbance $(280 \mathrm{~nm})(\square)$ and radioactivity (\% of total d.p.m. recovered; $\left[{ }^{3} \mathrm{H}\right]$ leucine incorporation) ( ) profiles of proteins secreted by day-15 pregnant guinea-pig endometrium cultured for $24 \mathrm{~h}$, after analysis on Sephacryl S-200HR.

not occur if the guinea-pig became pregnant. In ovariectomized guinea-pigs, progesterone alone had no stimulatory effect on endometrial protein secretion, whereas oestradiol alone caused a threefold increase in the amount of endometrial protein released. Progesterone reduced this stimulatory effect of oestradiol to a twofold increase.

The amounts of proteins freshly synthesized and secreted by guinea-pig endometrium (as indicated by the incorporation of $\left[{ }^{3} \mathrm{H}\right]$ leucine) increased 2.1-fold between day 7 and day 15 of the cycle, which is in agreement with results of Riley and Poyser (1989). This increase did not occur in pregnant guinea-pigs. In ovariectomized guinea-pigs, progesterone caused a 1.3-fold increase in the amount of $\left[{ }^{3} \mathrm{H}\right]$ leucine-containing protein produced. Oestradiol alone stimulated the production and secretion of $\left.{ }^{3} \mathrm{H}\right]$ leucine-containing proteins 2.9 -fold, whereas oestradiol acting on a progesterone-primed uterus increased the output of $\left[{ }^{3} \mathrm{H}\right]$ leucine-containing proteins 3.5 times. Oestradiol treatment therefore increased the amount of total protein secreted (i.e. 'preformed' plus 'freshly synthesized'), and increased the amount of freshly synthesized proteins secreted. However, progesterone treatment had two different actions. It had no effect on the amount of total protein secreted, and reduced the stimulatory effect of oestradiol on total protein secretion. However, progesterone increased the amount of freshly synthesized protein secreted, and when it was administered with oestradiol caused a further stimulation of the amount of freshly synthesized protein secreted. Proteins secreted by the guinea-pig endometrium were acidic. This result is in agreement with the study of Chaminadas et al. (1989) which showed that radiolabelled proteins secreted by guineapig endometrial cells in culture had acidic pI values.

Analysis of the $\left[{ }^{3} \mathrm{H}\right]$ leucine-containing proteins secreted by day-7 endometrium by Sephacryl S-200HR showed that several proteins were present in relatively small amounts (including a protein of $99.8 \mathrm{kDa}$ ), plus a protein in a relatively larger quantity with a molecular mass of $218.8 \mathrm{kDa}$. Between day 7 and day 15 of the cycle, the relative amounts of the $98.8 \mathrm{kDa}$ pro- tein synthesized and secreted by the endometrium increased 5.5 -fold, and another protein with a molecular mass of $192.1 \mathrm{kDa}$ was synthesized. These two proteins were the major proteins synthesized and secreted (as indicated by $\left[{ }^{3} \mathrm{H}\right]$ leucine incorporation) by the day 15 nonpregnant endometrium. The $99.8 \mathrm{kDa}$ protein was glycosylated to a small extent. The 99.8 and $192.1 \mathrm{kDa}$ proteins were apparently not synthesized and secreted by day-15 pregnant guinea-pig endometrium. However, labelled proteins with molecular masses of 77.1, 114.0 and $168.0 \mathrm{kDa}$ were produced by the day- 15 pregnant endometrium.

In ovariectomized guinea-pigs, progesterone treatment did not stimulate the synthesis and secretion of $\left[{ }^{3} \mathrm{H}\right]$ leucine-containing proteins with molecular masses of 99.8 and $192.1 \mathrm{kDa}$. Oestradiol treatment did stimulate the synthesis of the $192.1 \mathrm{kDa}$ protein, and also proteins of molecular mass 87.8 and $67.6 \mathrm{kDa}$. However, oestradiol treatment following progesterone administration stimulated the synthesis and secretion of $\left[{ }^{3} \mathrm{H}\right]$ leucinecontaining proteins with molecular masses of 99.8 and $192.1 \mathrm{kDa}$. Thus, oestradiol acting on a progesterone-primed uterus produced a similar profile of proteins synthesized and secreted by the endometrium to that produced by day 15 nonpregnant endometrium (which is also under oestradiol dominance following progesterone-priming by the endogenous hormones).

Analysis of the day- 15 secreted proteins from nonpregnant endometrium by SDS-PAGE produced radioactive bands at 17.4, 74.3 and 81.3 kDa. These molecular masses are lower than the two main radioactive protein peaks seen on Sephacryl S$200 \mathrm{HR}$ at 99.8 and $192.1 \mathrm{kDa}$. This may be for several reasons, namely (i) the proteins separated by Sephacryl S-200HR consist of one or more polypeptides which dissociated and ran separately on SDS-PAGE, (ii) the proteins are unstable in SDS and breakdown into smaller polypeptide chains (the 81.3 and $17.4 \mathrm{kDa}$ protein bands may be derived from the $99.8 \mathrm{kDa}$ protein, since their combined molecular mass is $98.7 \mathrm{kDa}$, which is 

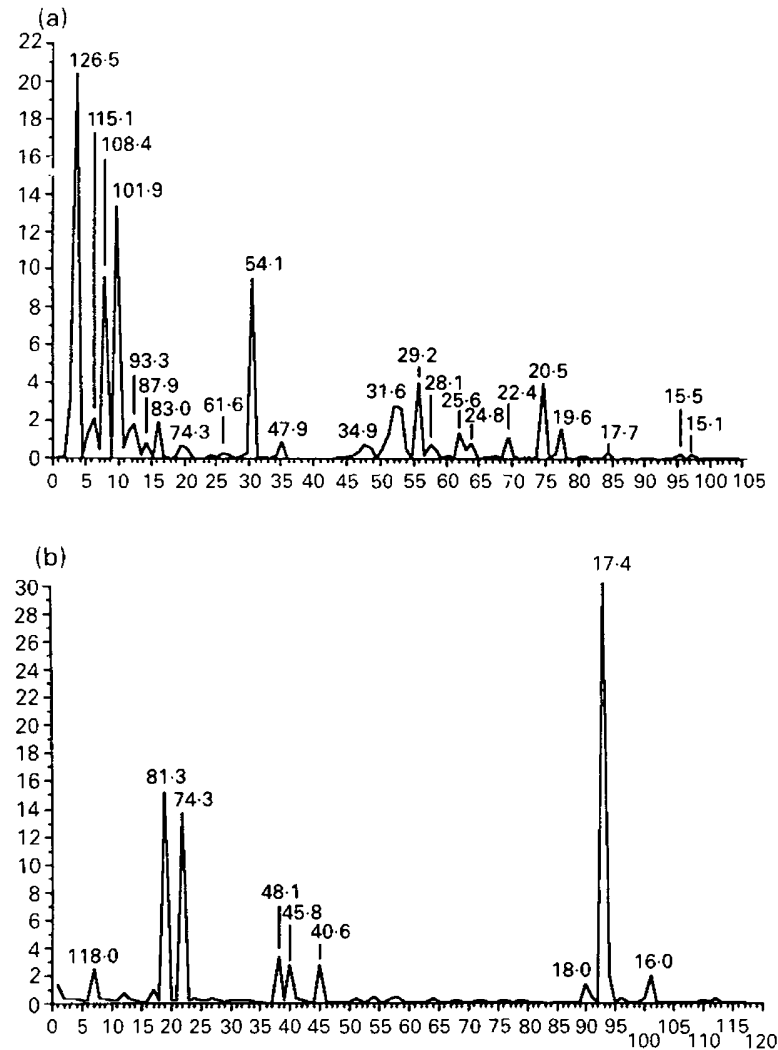

(c)

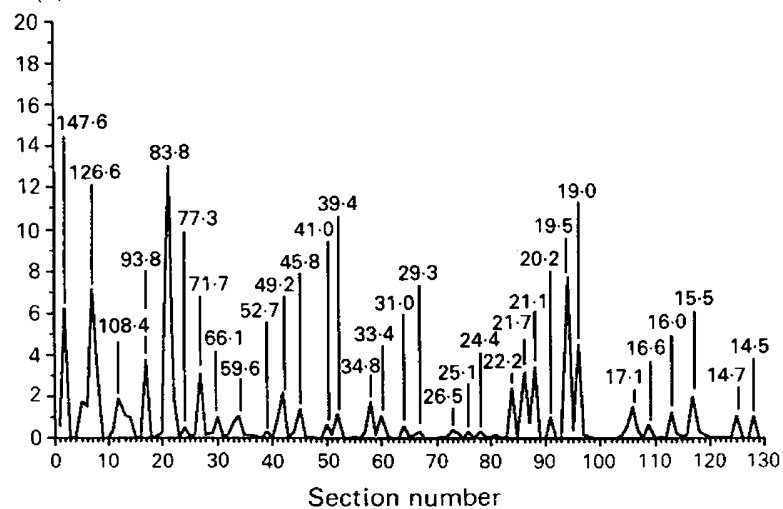

Fig. 7. Radioactivity profiles (\% of total d.p.m. recovered from gel; $\left[{ }^{3} \mathrm{H}\right]$ leucine-incorporation) of proteins secreted by (a) day-7 nonpregnant, (b) day-15 nonpregnant, and (c) day-15 pregnant endometrium cultured for $24 \mathrm{~h}$, after analysis by SDS-PAGE.

within the margin of error in calculating molecular masses), and (iii) assigning a molecular mass of $99.8 \mathrm{kDa}$ to this protein on Sephacryl S-200HR may be an overestimate since, in the calibration curve for Sephacryl S-200HR (Fig. 1), the protein standard (i.e. bovine serum albumin) with a known molecular mass of $66.0 \mathrm{kDa}$ consistently lay off the calibration curve and therefore had an apparent molecular mass of $83.7 \mathrm{kDa}$. If the same phenomenon occurs with other proteins of similar molecular mass, the protein at $81.3 \mathrm{kDa}$ (or even at $74.3 \mathrm{kDa}$ ) may be the same protein that runs as the $99.8 \mathrm{kDa}$ protein on Sephacryl $\mathrm{S}-200 \mathrm{HR}$. Further studies are needed to investigate these three possibilities for the discrepancy between the Sephacryl-S-
$200 H R$ and SDS-PAGE profiles of the day-15 endometrial, secreted proteins. However, the 17.4, 74.3 and $81.3 \mathrm{kDa}$ proteins were present in much smaller quantities, if at all, in the SDSPAGE profile of $\left[{ }^{3} \mathrm{H}\right]$ leucine-containing proteins synthesized and secreted by day-7 nonpregnant and day- 15 pregnant guinea-pig endometrium.

Overall, this study has shown that the synthesis and secretion of proteins by the guinea-pig endometrium increases between day 7 and day 15 of the cycle, and that pregnancy suppresses this increase. These results are similar to those observed for $\mathrm{PGF}_{2 \alpha}$ synthesis and secretion by the guinea-pig uterus (Blatchley et al., 1972, 1975; Earthy et al., 1975; Antonini et al., 1976). Oestradiol acting on a progesterone-primed uterus is the optimum stimulus for the greatest increase in endometrial protein synthesis and secretion, and this combination of ovarian steroids is precisely the same stimulus for maximum endometrial $\mathrm{PGF}_{2 \alpha}$ production in guinea-pigs (Blatchley and Poyser, 1974; Poyser, 1983a). Consequently, the present findings are consistent with the previous studies using protein synthesis inhibitors (Poyser, 1979; Poyser and Riley, 1987; Riley and Poyser, 1989; Leckie and Poyser, 1990) which indicated that increased endometrial $\mathrm{PGF}_{2 \alpha}$ synthesis depends on increased endometrial protein synthesis. Furthermore, the lack of increase in endometrial protein synthesis and secretion in early pregnancy in guinea-pigs is associated with a lack of increase in uterine $\mathrm{PGF}_{2 \alpha}$ production, which again suggests a cause and effect relationship. This is in agreement with the findings of Poyser (1984) that oestradiol administered to early pregnant guinea-pigs could not overcome the inhibitory effect of the conceptus on uterine $\mathrm{PGF}_{2 \alpha}$ production, nor could it stimulate an increase in the amount of prostaglandin endoperoxide synthase present in the endometrium. Normally, endometrial prostaglandin endoperoxide synthase concentrations increase between day 7 and day 15 of the cycle, an effect which is due to oestradiol stimulation (Poyser, 1983a, b). This increase in enzyme concentration does not occur in early pregnancy nor can it be induced by oestradiol in early pregnant guinea-pigs (Poyser, 1984). Thus it appears that, in the guinea-pig, the conceptus prevents oestradiol acting on a progesterone-primed uterus to stimulate endometrial $\mathrm{PGF}_{2 \alpha}$ synthesis and secretion by inhibiting protein synthesis.

In ovariectomized guinea-pigs, oestradiol acting on a progesterone-primed uterus stimulated the synthesis and secretion of two major proteins of molecular masses 99.8 and $192.1 \mathrm{kDa}$. These were also the two major proteins synthesized and secreted by day- 15 nonpregnant guinea-pig endometrium, indicating that in vivo the same combination of ovarian steroid hormones is probably responsible for their synthesis. These two proteins were produced in very much smaller quantities, if at all, by day- 7 nonpregnant and day-15 pregnant guinea-pig endometrium. Consequently, the 99.8 or the $192.1 \mathrm{kDa}$ protein or both proteins may be involved in the activation of $\mathrm{PLA}_{2}$ and the consequent stimulation of endometrial $\mathrm{PGF}_{2 \alpha}$ synthesis.

This study was supported by a grant from the MRC.

\section{References}

Antonini R, Turner TT and Pauerstein CJ (1976) The hormonal control of the guinea-pig corpus luteum during early pregnancy Fertility and Sterility $\mathbf{2 7}$ $1322-1325$ 
Basha SMM, Bazer FW and Roberts RM (1979) The secretion of uterine specific, purple phosphatase by cultured explants of porcine endometrium dependency upon the state of pregnancy of the donor animal Biology of Reproduction $20431-441$

Blatchley FR and Poyser NL (1974) The effect of oestrogen and progesterone on the release of prostaglandins from the uterus of the ovariectomised guineapig Joumal of Reproduction and Fertility 40 205-209

Blatchley FR, Donovan BT, Horton EW and Poyser NL (1972) The release of prostaglandins and progestin into the utero-ovarian venous blood of guineapigs during the oestrous cycle and following oestrogen treatment journal of Physiology $22269-88$

Blatchley FR, Maule Walker FM and Poyser NL (1975) Progesterone, prostaglan$\operatorname{din} \mathrm{F}_{2 \alpha}$, and oestradiol in the utero-ovarian venous plasma of non-pregnant and early, unilaterally pregnant guinea-pigs Joumal of Endocrinology 67 225-229

Brenner RM and West NB (1975) Hormonal regulation of the reproductive tract in female mammals Annual Review of Physiology 37 273-302

Chaminadas G, Remy-Martin J-P, Alkhalaf M, Propper AY and Adessi GL (1989) Effect of progesterone on protein synthesis and secretion by cultured epithelial cells from guinea-pig endometrium Cell and Tissue Research $\mathbf{2 5 7}$ 129-136

Downing I and Poyser NL (1983) Estimation of phospholipase A2 activity in guinea-pig endometrium on Days 7 and 16 of the estrous cycle Prostaglandins, Leukotrienes and Medicine 12 110-117

Earthy M, Bishop C and Flack JD (1975) Progesterone and prostaglandin F concentrations in utero-ovarian venous plasma of cyclic guinea-pigs Journal of Endocrinology $6411 \mathrm{P}-12 \mathrm{P}$

Joshi HS, Watson DJ and Labhsetwar AD (1973) Ovarian secretion of oestradiol, oestrone, 20-dihydroprogesterone and progesterone during the oestrous cycle of the guinea-pig Joumal of Reproduction and Fertility 35 177-182

Laemmli UK (1970) Cleavage of structural proteins during the assembly of the head of bacteriophage Nature $227680-686$
Leckie CM and Poyser NL (1990) The effects of cholera toxin, pertussis toxin, sodium fluoride and $\alpha$-interferon on prostaglandin production by the guineapig endometrium Joumal of Reproduction and Fertility 89 325-333

Lowry OH, Roseborough NJ, Farr AL and Randall RL (1951) Protein measurement with folin phenol reagent Journal of Biological Chemistry 193 265-273

Poyser NL (1979) Effects of actinomycin D on uterine prostaglandin production and oestrous cycle length in guinea-pigs Journal of Reproduction and Fertility 56 559-565

Poyser NL (1983a) Effect of treating ovariectomised guinea-pigs with estradiol and progesterone on basal and A23187-stimulated release of prostaglandins from the uterus superfused in vitro Prostaglandins, Leukotrienes and Medicine 11 345-360

Poyser NL (1983b) Differential stimulation of prostaglandin and thromboxane synthesising capacities in guinea-pig uterus and ovary Prostaglandins, Leukotrienes and Medicine 10 163-177

Poyser NL (1984) Prostaglandin production by the early pregnant guinea-pig uterus in relation to implantation and luteal maintenance, and the effect of oestradiol Joumal of Reproduction and Fertility 72 117-127

Poyser NL and Brydon LJ (1983) Prostaglandin release from the guinea-pig uterus superfused in vitro: effect of stage of estrous cycle, progesterone, estradiol, oxytocin and A23187 Prostaglandins 25 443-456

Poyser NL and Riley SC (1987) Effect of actinomycin D on prostaglandin synthesis by and output from the guinea-pig uterus Prostaglandins, Leukotrienes and Medicine 28 153-168

Riley SC and Poyser NL (1987) Effects of oestradiol, progesterone, hydrocortisone and oxytocin on prostaglandin output from the guinea-pig endometrium maintained in tissue culture Prostaglandins 34 535-552

Riley SC and Poyser NL (1989) Is protein synthesis necessary for prostaglandin production by guinea-pig endometrium? Joumal of Reproduction and Fertility $8673-89$ 